\title{
独立成分分析を用いた機械振動系のブラインド同定実験 と構造変化検出*
}

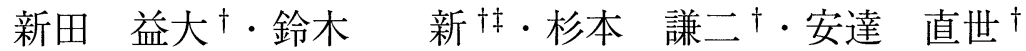

\begin{abstract}
Blind Identification of Mechanical Systems via Independent Component Analysis and Detection of Structure Change*
\end{abstract}

\author{
Masuhiro Nitta $^{\dagger}$, Arata SuzukI ${ }^{\dagger \ddagger}$, Kenji Sugimoto ${ }^{\dagger}$ and Naotoshi AdACHI ${ }^{\dagger}$
}

\begin{abstract}
This paper studies a method for blind identification based upon independent component analysis. By observing vibration of a mechanical system subject to unknown but independent signals, the method makes it possible to identify partial data of the system parameter and to estimate the unknown input signals. Then, by monitoring independence of the estimated signals, the paper gives a method for detecting the change in mechanical parameter. This can be applied to fault detection of operating machines without any special sensor for the fault. An experiment with a flexible structure is carried out to verify these methods.
\end{abstract}

\section{1.はじめに}

システムに複数の互いに独立な信号が加わり，それら が線形に混合された信号として観測される状況で，観測 信号のみから独立な入力信号を推定するという独立成分 分析 (Independent Component Analysis: ICA) の方 法論が，近年，注目を集めている $[1-6]$.

ICA の有用性は，様々な適用分野からも明らかであ る。たとえば，音響信号処理では，音声の分離に用いら れ [7], 石油精製プラントや化学プラントでは, 有毒ガス 漏洩検出などが提案されている $[8]$. また, 生体信号解析 では脳活動解析へ適用しており [9], 画像認識では肌の状 態観測へ適用されている [10]. さらに, 制御工学の分野 ではプロセス管理への適用が報告されている [11].

しかしながら，制御工学で広く ICA が活用されている とは必ずしもいえない. その理由の一つは, 制御では動 的なシステムを取り扱うためである。動的な混合を扱っ た研究として，たとえば音声の分野では残響を考慮した 信号分離のために, FIR フィルタによる混合を受ける場 合の分離問題が扱われている [3]. しかし解法が困難なた

* 原稿受付 2005 年 4 月 1 日

†奈良先端科学技術大学院大学 情報科学研究科 Graduate School of Information Science, Nara Institute of Science and Technology; Takayama cho, Ikoma city, Nara 6300192, JAPAN

‡ 象印マホービン(株) ZOJIRUSHI Corporation Key Words: blind system identification, independent component analysis, fault detection.
めに周波数領域で分離することによって静的な混合に帰 着させる方法が主流である [4]. いっぽう，制御で扱うシ ステムは内部フィードバック構造を有するため IIR フィ ルタによる混合を考える必要があるが, 近似的に FIR フィルタの分離問題として扱うとタップ数が増大するた めに多量のデータが必要となるし, 周波数帯域が限られ るため時間領域での解析が望ましい場合もある。そこで 著者らは，ある種の状態空間モデルにICAを適用し，多 变量 AR モデルに対するブラインド同定アルゴリズム （以下，VAR-ICA とよぶ）を提案している [12-14].ま た，これを応用した外乱低減法も提案している [15].

本論文ではVAR-ICA の応用として機械システムの構 造変化検出について議論する。従来, ICA は音声などに 代表される信号処理の分野で活発に研究されてきたが, それらは信号そのものの分離が主たる目的であった。こ れに対し，構造変化検出では分離した信号と分離系の両 方に着目している点が特徴であり, 主たる論旨はつぎの 2 点である。

(1) 柔軟フレームによる機械振動系を製作し, VARICAの有効性を実験によって検証する. VAR-ICA では対象システムや入力信号にいくつかの仮定が あり，これらがどの程度まで制約になるかは，理 論だけでは明らかでない。逆に，仮定を満たさな くても部分的に有効なこともあるため, 実機によっ て確認する.

(2) VAR-ICAの応用として, システムに何らかの変化 
が生じた際の検出法を提案する。通常のシステム 同定では，同定後に制御入力を設計するので，入 力が未知とは考えにくい.しかし，外乱のように 未知の入力信号が印加される場合や，入力がアク チュエータの飽和などにより不確かになる場合な ど，入力信号を利用できないことも多々ある。こ ういった状況下で，故障や劣化によってシステム の構造が変化すれば，出力信号にも影響する。こ のとき, 構造の変化を出力のみから検出できれば, 実用上も望ましい。そこで，これを実験によって 確認する。

以下，それぞれについて補足する。(1)に関しては，多 変量 AR モデルという仮定が必ずしも満たされなくても, システムに対する一部の情報が得られることを示す．(2) については, 出力信号には入力信号とシステムの伝達特 性の両方の影響が現れるため, それのみでは入力の変化 と伝達特性の変化（構造の変化）とを区別することはで きないが，ICAの適用により構造の変化を正しく検出で きることを示す.

この目的を達するために，伝達行列の推定には VARICA を用い，構造変化検出には，なるべく短時間で効率 よく検出を行うためにFastICA[2] を用いる方法を提案 する．以下，2.で提案するアルゴリズムを説明し，3.で ARMA モデルの同定シミュレーションを通じて変化の 検出が可能であることを示し，4. で実験とその結果につ いて述べる。

\section{2. 変化検出法}

\subsection{VAR-ICA の概略}

本節では準備のために，標準的な ICA の問題設定 と学習則，そして動的システムに対する ICA である VAR-ICAの概略を説明する。

ICA は, 未知の入力信号 $s(t)$ が, 未知の混合行列 $A$ によって

$$
\eta(t)=A s(t)
$$

と (瞬時) 混合されるとき, $\eta(t)$ のみから $s(t)$ と $A$ を復 元する手法である.このとき $s(t)$ の各成分は統計的独立 であり，混合行列 $A$ は正則な定数行列であるという前提 がある．信号復元 (分離) は逆混合

$$
\hat{s}(t)=W \eta(t)
$$

を考え， $\hat{s}(t)$ が独立になるように分離行列 $W$ を学習さ せる方法がとられる．学習にはいくつかの手法 $[1,2,5]$ が 提案されているが，お拉むねつぎの学習則で $W$ を更新 する。

$$
\Delta W=\left(I-\mathcal{E}\left[\phi(\hat{s}) \hat{s}^{\mathrm{T}}\right]\right) W
$$

ここで $\mathcal{E}[\cdot]$ は期待值を表す記号， $\phi(\cdot)$ は適当な非線形べ
クトル值関数 $[6], I$ は単位行列である.

学習が収束し, $W=A^{-1}$ となれば入力 $s(t)$ が完全に復 元できるが，独立性のみを基準にしているので，一般に， 適当な対角行列 $\Gamma$ と置換行列 $P$ によって $W=P \Gamma A^{-1}$ の形で求まる。したがって, 再現された信号 $\hat{s}(t)$ は振幅 と順序の不定性を残しており, $s(t)$ と必ずしも一致はし ないことを注意する。

さて，上記の問題設定は静的な混合（瞬時混合）であ るが，これを動的システムによる混合

$$
y(t)=G(z) u(t)
$$

に拡張する手法について説明する。ここで $u(t)$ は未知入 力信号, $y(t)$ は出力信号であり $G(z)$ は安定かつ可逆で 最小位相な離散時間伝達行列である。また, $z$ は単位シ フト演算子であり, $z u(t)=u(t+1)$ を意味する.

静的な混合の場合と同様に, $u(t)$ の各成分は独立であ るとし， $y(t)$ の情報のみから $u(t)$ を復元することを試み る。これは静的な混合とは格段に困難な問題設定である が, 新田ら $[12,13]$ は以下の仮定のもとで, ある種の解 法を与えている。

まず (4) 式において，システム $G(z)$ がつぎのような 左既約分解で表されるとする.

$$
\begin{aligned}
& G(z)=D^{-1}(z) N(z) \\
& D(z)=z^{\mu} I+z^{\mu-1} D_{1}+\cdots+D_{\mu} \\
& N(z)=z^{\mu} N_{0}
\end{aligned}
$$

ここで $\mu$ は既知の自然数であり, 分母多項式行列の次数 である。また $N_{0}=\left(n_{i j}^{0}\right)$ は正則で

$$
n_{i i}^{0}=1, \quad\left|n_{i j}^{0}\right|<1 \quad(i \neq j)
$$

を仮定する．この仮定はICA における振幅の不定性を避 けるためのものであり，一般性は失わない.

このとき, 入出力関係は, $D(z) y(t)=N(z) u(t)$ とな り，さらに $z$ がシフト演算子であることから

$$
\underbrace{\left[\begin{array}{c}
y(t-\mu) \\
\vdots \\
y(t-1) \\
y(t)
\end{array}\right]}_{\eta(t)}=\underbrace{\left[\begin{array}{cccc}
I & & O & O \\
& \ddots & & \vdots \\
O & & I & O \\
-D_{\mu} & \ldots & -D_{1} & N_{0}
\end{array}\right]}_{A} \underbrace{\left[\begin{array}{c}
y(t-\mu) \\
\vdots \\
y(t-1) \\
u(t)
\end{array}\right]}_{s(t)}
$$

という状態空間表現が得られる。( $O$ は零行列である.) こ の式を $\eta(t)=A s(t)$ と略記するとき，入力ベクトル $s(t)$ が

$$
s(t)=\left(y^{\mathrm{T}}(t-\mu), \ldots, y^{\mathrm{T}}(t-1), u^{\mathrm{T}}(t)\right)^{\mathrm{T}}
$$

となり，独立成分 $u(t)$ 以外を含むため既存の ICA で信 号復元を行うことができない. しかし入出力ベクトルに $y(t-k)(k=1, \ldots, k)$ という項を含むことに着目すると， 
この問題に特化したICA のアルゴリズム（VAR-ICA） を得ることができる。

結果として分離行列 $W$ の学習則は

$$
\Delta W=T\left(I-\mathcal{E}\left[\phi(\hat{s}) \hat{s}^{\mathrm{T}}\right]\right) W
$$

で与えられる。ここで $T$ は次式で定義されるブロック対 角行列である。

$$
T=\operatorname{block} \operatorname{diag}(O, \ldots, O, I)
$$

これは通常のICA アルゴリズムにブロック対角行列 $T$ を左から掛けたものに等しく, $s(t)$ のうち $u(t)$ のみを ICA で復元していることになる. (詳細は $[13]$ 参照.)

独立成分の復元は，(6) 式に対応するつぎの分離系に おいて，Wの最下位ブロックに配置されたパラメータ行 列 $W_{k}$ を(8) 式を用いて同時に更新することで行われる.

$$
\underbrace{\left[\begin{array}{c}
y(t-\mu) \\
\vdots \\
y(t-1) \\
\hat{u}(t)
\end{array}\right]}_{\hat{s}(t)}=\underbrace{\left[\begin{array}{cccc}
I & & O & O \\
& \ddots & & \vdots \\
O & & I & O \\
W_{\mu} & \ldots & W_{1} & W_{0}
\end{array}\right]}_{W} \underbrace{\left[\begin{array}{c}
y(t-\mu) \\
\vdots \\
y(t-1) \\
y(t)
\end{array}\right]}_{\eta(t)}
$$

学習が収束するとVAR-ICA の分離行列 $W$ は

$$
W=\left[\begin{array}{cccc}
I & & O & O \\
& \ddots & & \vdots \\
O & & I & O \\
N_{0}^{-1} D_{\mu} & \ldots & N_{0}^{-1} D_{1} & N_{0}^{-1}
\end{array}\right]
$$

となるから, 分離系 $H(z)$ は

$$
\begin{aligned}
& H(z)=\left(I z^{\mu}\right)^{-1} \\
& \quad \times\left(N_{0}^{-1} z^{\mu}+N_{0}^{-1} D_{1} z^{\mu-1}+\ldots+N_{0}^{-1} D_{\mu}\right)
\end{aligned}
$$

として求めることができる.

分離系 $H(z)$ が求まると, 元のシステムは $\hat{G}(z)=$ $H^{-1}(z)$ として推定される. ICA を用いたシステム同定 の特徵は, 逆システムを推定するということにあり, こ れには入力信号を用いないため，未知入力システム同定 もしくはブラインド同定とよぶ.

いっぽう，分離系をFIRフィルタとして推定する従来 の時間遅れ作用素を用いた方法 [16]でも，パラメータ 行列 $W_{k}$ を決定することができる．この方法を便宜的に VAR-ICA と同様の形式で表すと

$$
\underbrace{\left[\begin{array}{c}
\hat{u}(t-\mu) \\
\vdots \\
\hat{u}(t-1) \\
\hat{u}(t)
\end{array}\right]}_{\hat{s}(t)}=\underbrace{\left[\begin{array}{cccc}
W_{0} & O & \ldots & O \\
\vdots & \ddots & \ddots & \vdots \\
W_{\mu-1} & \ldots & W_{0} & O \\
W_{\mu} & W_{\mu-1} & \ldots & W_{0}
\end{array}\right]}_{W} \underbrace{\left[\begin{array}{c}
y(t-\mu) \\
\vdots \\
y(t-1) \\
y(t)
\end{array}\right]}_{\eta(t)}
$$

という形で分離系 $W$ を学習することになる．この方法
では各パラメー夕行列を個別に学習する必要があり, 学 習効率の観点からは疑問が残る。これに対し VAR-ICA は分離系を近似なしに厳密に推定することができ，しか もパラメータ行列を同時に学習するアルゴリズムなので， 逆システム $H(z)$ を得るのに有利である.

\section{2 構造変化検出アルゴリズム}

上で述べたブラインド同定法には，つぎのような応用 が考えられる. 入力と出力の両方を用いてシステムを 同定するのが通常のシステム同定であるが，実際には アクチュエータの飽和によって操作量が未知となる場合 や，未知外乱が定常的に加わる場合など，複数の入力が 未知の場合も十分にあり得る。これらは要因が異なるの で，独立な值をとると仮定するのは自然である ${ }^{1}$.そこ で, VAR-ICAにより未知入力信号から出力 (観測) 信 号への伝達行列を得ることができる。こうしてあらかじ め未知入力から出力への影響 (システム構造) がわかっ ていれば，個々の入力を再現したりシステムの様子を監 視することができるので有用と考えられる.

そこで, 本論文では故障や経年変化により構造が変化 したときの検出にVAR-ICA を適用することを提案する. とくに，常時システムの出力を監視しておき，構造が突 発的に変化したとき，これをなるべく短時間で検出する 手法を以下で述べる.

\subsection{1 逆システムによる定常監視}

独立な信号が動的システム $G(z)$ に入力されていると き, VAR-ICA により

$$
H(z) G(z)=I
$$

なる分離系 $H(z)$ を得ることができる。これは未知入力 の挙動を観測することにも利用できるが，ここでは $G(z)$ の構造 (具体的にはパラメー夕行列 $N_{0}, D_{i}(i=1, \ldots, \mu)$ ) が変化したときの検出方法を検討する.

単純に考えつくのは, VAR-ICA を繰り返し適用して, 一定時間ごとに $G(z)$ の推定結果を監視するという方法 である。しかし，VAR-ICA は自然勾配法に基づくアル ゴリズムであるためにパラメータ行列の繰り返し学習に は時間を要するし，推定パラメータが多いために，ある 程度のデー夕点数も必要となる. 他方, 構造変化検出の 観点では，変化の事実を直ちに知ることが問題であり， 変化後のパラメー夕行列を求める必要はあまりない。む しろ複数のパラメータ行列から構造変化を検出すること は難しく，自動化にふさわしくない.この問題を解決す るために，さらに ICAを適用することを考える。

\subsubsection{FastICA の援用}

常時, システム同定を繰り返して変化を検出するのは 上述の問題があるので, 逆システムの構築後はこれを固

\footnotetext{
${ }^{1}$ 本論文では，正規分布に従う入力信号は一つ以上含ま ないと仮定する．これはICA では本質的に多次元正規 分布に従う信号を分離できないためである.
} 
定し，分離された信号をモニタすることによって構造の 変化を検出する手法を提案する.

(4) 式に扔いて, $y(t)$ から $u(t)$ を推定する逆システム $H(z)$ 2.1 の手法（VAR-ICA）で求包, この系を通過 した分離信号 $\hat{u}(t)$ を生成する。

$$
\hat{u}(t)=H(z) y(t)
$$

このとき, システムに何らかの変化が発生し伝達行列 $G(z)$ が $G^{\prime}(z)$ に変化すれば, $H(z)$ は当然 $G^{\prime}(z)$ の逆シ ステムではないので, $\hat{u}(t)$ は独立にならないはずである 1 (Fig. 1) 。したがって, 通常時に分離系 $H(z)$ を一度推 定して抒けば, $\hat{u}(t)$ の独立性を調べることで構造変化の 検出が可能となる.

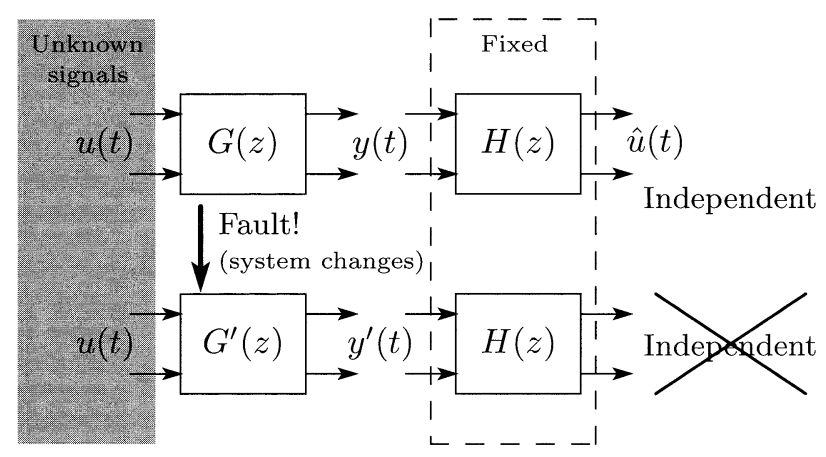

Fig. 1 Block diagram of the proposed algorithm

しかし，一般に独立であることを直接示すのは困難で あるので，FastICAを用いた簡便な方法を提案する。

まず, 分離信号 $\hat{u}(t) \in \mathbb{R}^{n}$ に FastICA を適用しょう. すると

$$
\tilde{u}(t)=F \hat{u}(t)
$$

のように分離行列 $F$ が決定され，独立成分 $\tilde{u}(t)$ が得られ る. 構造変化前 (Fig. 1 上) は, $\hat{u}(t)$ は独立だから, 分 離行列 $F$ は振幅と順序の不定性の影響を受けるが, 適当 な置換行列によって対角行列に変換できる. 構造変化後 (Fig.1下) は， $\hat{u}(t)$ は独立でなくなるが, FastICA で はチャンネルごとに順に独立な信号を取り出す算法であ るため, それでも学習は収束して $F$ が算出される。 ただ し, 正しい分離を与えないため $F$ は置換しても対角行列 にならないか，そもそも置換行列が存在しない。

これらのことを，つぎのようにして系統的に判定しよ j. まず， $F$ の第 $i$ 行について，その行べクトルの要素の

\footnotetext{
${ }^{1} G(z)$ が $G^{\prime}(z)$ に変化しても独立成分が得られるのは $H(z) G^{\prime}(z)=\Gamma P$ となる場合である. $(\Gamma, P$ はそれぞ れ適当な対角行列拉よび置換行列である.） $\Gamma$ は入力信 号の振幅が変化した効果を, $P$ は入力源の入れ替わり （もしくは出力側センサの付け替え）が生じたことを 意味しているが, 物理システムがこのように変化する ことはまれであり，本論文ではこのような変化は生じ ないと仮定する.
}

うち絶対值が最大の要素を 1 ，その他を 0 とした自然基底 (行) ベクトル $e_{i}$ を求め, 置換行列 $E=\left(e_{1}^{\mathrm{T}}, \ldots, e_{n}^{\mathrm{T}}\right)$ を生 成する. $E$ がフルランクでない場合, $F$ には置換行列が存

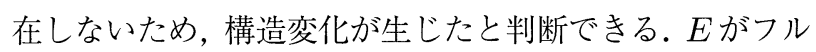
ランクの場合， $\bar{F}=F E$ として順序の不定性を取り除き, これを各列について規格化する.すなわち, $\bar{F}=\left(\bar{f}_{i j}\right)$ と するとき第 $j$ 列について $\bar{f}_{k j}=\bar{f}_{k j} / \bar{f}_{j j}(k=1, \ldots, n)$ とし て振幅を規格化する。規格化された行列を $\bar{F}^{\prime}$ とすると き，この行列の対角成分は 1 であり，もし非対角成分に 絶対值が 1 以上の成分があれば $F$ は対角優位ではなかっ たので，この場合も構造変化が生じたと判断する．対角 優位の度合いを数值として表すには, $n$ 次の単位行列を $I_{n}$ として

$$
\epsilon:=\left\|\bar{F}^{\prime}-I_{n}\right\|_{\mathrm{F}}
$$

のように非対角成分の 2 乗和で単位行列からの残差を定 義し，これを独立性の尺度として見積もればよい。ここ で\|・斯はフロベニウスノルムを表す.

このように, FastICA を用いると独立性の判断材料 として残差 $\epsilon$ みを与えることができ, 検査結果を評価 して警告を発す場合などには有益な情報となる。しかも FastICA の特徵である計算速度を生かすことができる. ただし，実用上は，正常時に $\epsilon$ を複数回計算しておき， それをもとに判定基準として䦨值を設定する必要がある.

以下に構造変化検出の処理手順をまとめる.

ステップ 1 機械システムが正常な状態で, VAR-ICA を用いて，逆システム $H(z)$ を求める.

ステップ 2 ステップ 1 で求めた $H(z)$ を固定し, 出力 信号 $y(t)$ から推定人力信号 $\hat{u}(t)$ を求める.

ステップ $3 \hat{u}(t)$ に FastICA を適用し, FastICAの分 離行列 $F$ を得る。

ステップ 4 機械システムの構造に変化がなければ，ス テップ 3 で求めた $F$ は対角優位な行列に変 換できる. 対角優位であるかを(16)式の残 差で測り正常時に取得した閾值と比較する.

ステップ 5 機械システムに構造変化が発生してない場 合は，ステップ 2 に戻る．構造変化が発生 した場合は，報知し運転を停止する。

\section{3. 数值シミュレーション}

提案した構造变化検出アルゴリズムが有効であるかを 確認するために数值シミュレーションを行った。まず, システムの伝達行列がVAR-ICA が仮定する多変量 AR モデルにならない場合, VAR-ICAによって, どの程度 の同定結果が期待できるのかを示し，その結果をもとに， 提案手法に従って構造変化の検出を行う.

\section{1 ブラインド同定}

想定するシステム $G(z)=D^{-1}(z) N(z)$ として，つき の多変量 ARMA モデルを用いた. 


$$
\begin{aligned}
& D(z)=I z^{2}+\left[\begin{array}{rr}
0.37 & 1.69 \\
-0.04 & 0.24
\end{array}\right] z+\left[\begin{array}{rr}
0.63 & 0.78 \\
-0.03 & 0.37
\end{array}\right] \\
& N(z)=\left[\begin{array}{rr}
1.97 & -0.39 \\
1.26 & 1.50
\end{array}\right] z+\left[\begin{array}{ll}
-1.09 & -0.69 \\
-0.62 & -0.21
\end{array}\right]
\end{aligned}
$$

このとき, 次数 $\mu$ (分母多項式行列 $D(z)$ の最高次数) を 2 および 5 としてブラインド同定を行った. その結果 をボード線図としてFig. 2 に示す。この図は，伝達行列 の各成分についてゲイン線図と位相線図を描き，それぞ れに対応させて配置したものである。たとえば， $(1,1)$ 成 分を左上に描くなどの対応関係である。図より，多変量 AR モデルという仮定を満たさず，かつ次数も真のもの とは異なっていても, システムの特徴（共振ピークなど） を正しく推定していることがわかる.

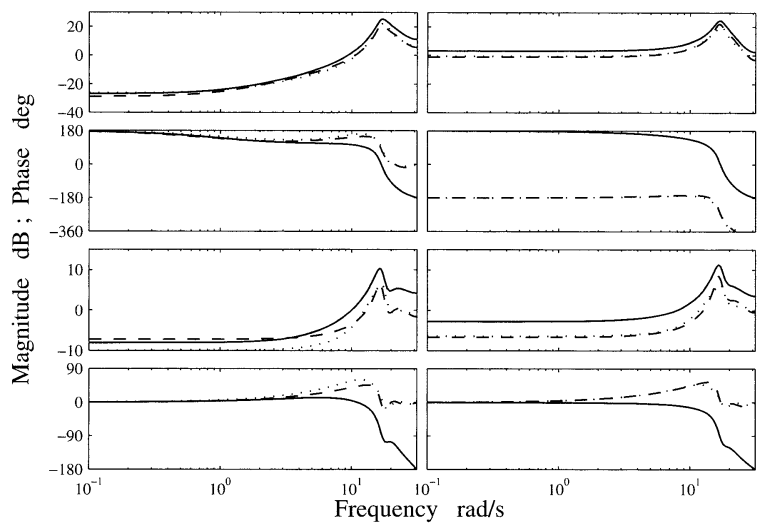

Fig. 2 Bode diagrams of each entry of $\hat{G}(z)$ (solid: true system, dashed: $\mu=2$, dotted: $\mu=5)$

\section{2 構造変化検出}

そこで $\mu=2$ の同定結果を用いて逆システム $H(z)$ を 取得し, これにより入力信号 $u(t)$ の推定 $\hat{u}(t)$ を求める. もし，逆システムが正しく推定されているならば $\hat{u}(t)$ は 独立であるはずであり，これを提案手法で確認する.

$\hat{u}(t)$ を FastICA で処理し, 分離行列 $F$ を得るとつぎ のようになった。

$$
F_{1}=\left[\begin{array}{rr}
-0.006 & 0.648 \\
-0.671 & -0.008
\end{array}\right]
$$

この分離行列に対して残差 $\epsilon$ を求めると $\epsilon=0.015$ とな る.これから, 分離系の推定に成功したとともに, シス テムに構造変化が起こっていないことがわかる.

いっぽう，二つの未知入力信号のうち，一つの信号を $\mathrm{M}$ 系列から正規乱数に変化させたとき, 分離行列は

$$
F_{2}=\left[\begin{array}{rr}
-0.672 & 0.010 \\
0.019 & -0.638
\end{array}\right]
$$

となり, 残差は $\epsilon=0.033$ となった. 残差が十分に 0 に近 いため，構造変化が生じていないことがわかる．

最後に, 構造の変化として分子多項式行列 $N(z)$ がつ
ぎのように変化した場合を考える。

$$
\bar{N}(z)=\left[\begin{array}{ll}
-0.32 & -2.65 \\
-1.18 & -0.34
\end{array}\right] z+\left[\begin{array}{ll}
-1.83 & -0.18 \\
-0.19 & -0.66
\end{array}\right]
$$

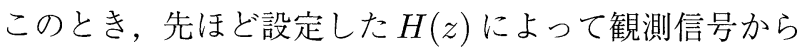
入力信号を推定し，それにFastICAを適用した結果，つ ぎの分離行列を得た。

$$
F_{3}=\left[\begin{array}{rr}
0.329 & -0.191 \\
-0.505 & -0.756
\end{array}\right]
$$

この分離行列に対して残差を求めると $\epsilon=1.555$ となっ た.この残差は先の 2 例と比べても 0 より十分に大きい L, この場合は $F_{3}$ は対角優位でもないため, システム に構造変化が生じたと判断できる。

以上のシミュレーション結果より，VAR-ICA は，そ れ自身が仮定するよりも広いクラスのシステムを同定す ることができることがわかった．また，意図的に入力信 号を変化させても, 独立性を用いることで構造変化のみ を正しく検出できることもわかった．以上のことから， 提案した変化検出アルゴリズムが有効に機能することが 確認できた.

\section{4. 構造変化検出実験}

\section{1 実験装置}

提案した変化検出アルゴリズムを評価するために, 機 械システムの実験装置（Fig. 3）を製作した。

実験装置を構成するフレームは，ステンレスロッド （直径 $4[\mathrm{~mm}]$, 肉厚 $0.5[\mathrm{~mm}]$ ) を, 高さ $750[\mathrm{~mm}]$, 幅 $500[\mathrm{~mm}]$, 奥行き $500[\mathrm{~mm}]$ に組み合わせている.

この装置の上部に取り付けられたモータ・スライダ・ リンクから構成される部分は，機械システムの機構を 模擬した信号入力部であり，下部に取り付けられたモー

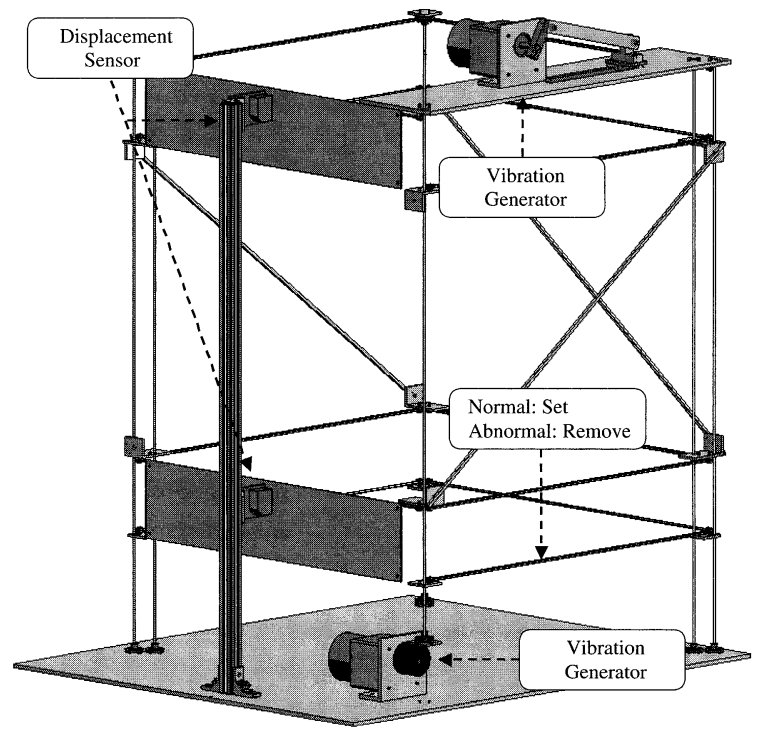

Fig. 3 Appearance of the experimental system 
夕と偏芯幅 $2[\mathrm{~mm}]$ を持つ偏芯円盤により構成される部 分は, 機械システムへ作用する外乱を模擬した外乱入 力部である. なお, 信号入力部, 外乱入力部ともに減 速比 1:5 のギヤヘッドを付けたブラシレス DC モータ (FED6P20PF-D3：日本サーボ製）を用いた。これらの 制御はマイコンボード（BTC050：ベストテクノロジー 製) で行っている。この機械システムはこれらのモータ による加振で振動している。

その振動を，実験装置の接地面より $250[\mathrm{~mm}]$ と $750[\mathrm{~mm}]$ の場所に取り付けた，レーザ変位センサ（ZX-LD40： オムロン製) で計測し，アンプ (ZX-LDA11：オムロン 製）を通して変位データが電圧出力として観測される. この信号を，パソコンの PCI バスに接続された A/D 変 換ボード (ADA16-32/2(PCI)F：コンテック製) によっ て逐次取得し，そのデータを提案アルゴリズムで処理す る (Fig. 4).

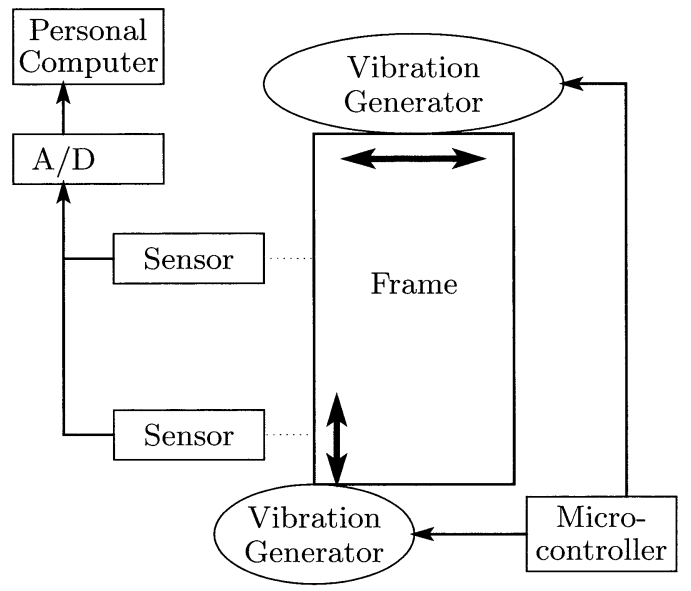

Fig. 4 Block diagram of the experimental system

\section{2 実験方法}

実際の構造変化は，ボルトが緩みいずれ脱落すると いった過渡的な場合が想定されるが，今回の実験では

(1) 機械システムが正常な状態

(2) 機械システムは正常な状態で, 操業スピードを上 げたと想定し，信号入力部のモータの印加電圧を 変化させた状態（印加電圧を $0.89[\mathrm{~V}]$ から $1.23[\mathrm{~V}]$ に変化させた。回転速度が速くなることに相当）

(3) 機械システムに変化が発生した状態 (Fig. 3 の底辺 に配置されたステンレスロッド固定ボルトが外れ た状態)

の 3 状態を設定し，それぞれ 51.2 秒のデータを取得し， これら (1)(2)(3) のデータを順番につなげることで擬似 的に構造変化発生時のデー夕を生成した。なお，(2) は 構造変化のみを識別できることを確認するためのデー夕 である。

まず, 最初の 51.2 秒を正常な状態として, 機械システ ムのブラインド同定を行い分離系 $H(z)$ を推定する. 構 造変化検出は, $H(z)$ を用いて推定した入力信号の独立
性を FastICAを用いて調べるが，この際の統計処理にも 51.2 秒ごとのデータを用いた。実験の夕イムチャートは Fig. 5 のようになる. 実験では未知入力信号として M 系 列信号を想定し, それを上下のモータへの印加電圧とし た。計測はサンプリング周期 100 ミリ秒にて行った。

\begin{tabular}{|c|c|c|c|}
\hline $\begin{array}{l}\begin{array}{l}\text { Blind system } \\
\text { identification }\end{array} \\
\text {. }\end{array}$ & $\longleftarrow \quad H(z)$ & $\begin{aligned} & 1 \\
\vdots & 1\end{aligned}$ & $\begin{array}{l}1 \\
1 \\
1 \\
\end{array}$ \\
\hline $\begin{array}{l}\text { Retrieving input } \\
\text { signals and } \\
\text { change detection } \\
\end{array}$ & $\longleftarrow$ & $\begin{array}{c}1 \\
1 \\
1\end{array}$ & $\begin{array}{c}1 \\
1 \\
1\end{array}$ \\
\hline $\begin{array}{l}\text { Situation of } \\
\text { experimental } \\
\text { system }\end{array}$ & Normal & $\begin{array}{l}\text { Normal, but } \\
\text { voltage change }\end{array}$ & Abnormal \\
\hline
\end{tabular}

Fig. 5 Timing chart of the experiment

\section{3 実験結果}

Fig. 6 にレーザ変位センサによる観測值を示す.上図, 下図がそれぞれ上下のセンサアンプの出力電圧に対応す る.また 0 51.2 秒までが通常時, 51.2〜102.4 秒にかけ ては上側のモータアンプのゲインが変化し，102.4秒に Fig. 3 にあるように，底辺に配置されたステンレスロッ ドの 1 本の締結が外れる事故が発生したと想定し，それ 以降，153.6秒までその信号を観測したとする.

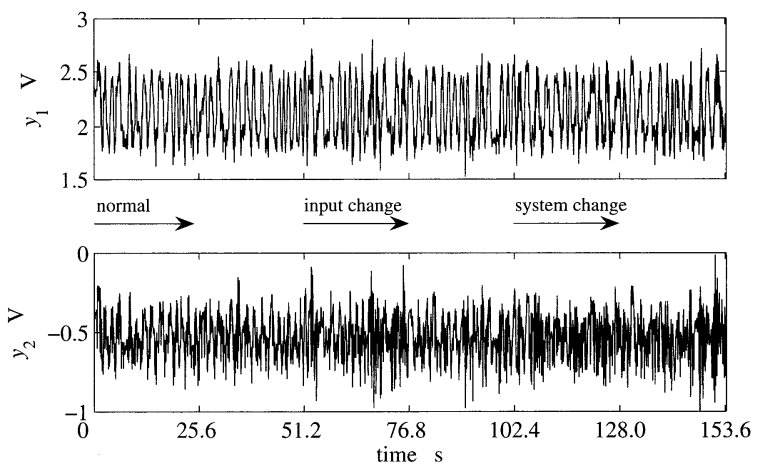

Fig. 6 Observed signals

まず, 分離系 $H(z)$ を推定するために次数 $\mu$ を決定 しなければならない.そこで正常時のデー夕に対して， $\mu=2,3, \ldots, 6$ と変化させてVAR-ICAによりブラインド同 定を行った。同定結果を Fig. 7 に示す. 図より $\mu=4,5,6$ では同様の周波数特性を有していることから, VARICA の次数 $\mu$ を 5 と設定した。 また，この同定結果か ら, VAR-ICA は, 適切な次数を設定すれば同様の特性 を得ることができるため，ある程度の頑健性も備えてい ることがわかる。なお， $\mu=5$ として 512 点のデータを 用いて逆システム $H(z)$ を推定したが，これには 7.18 秒 (Celeron, $2.2 \mathrm{GHz})$ の計算時間を要した.

この計算時間の短縮のために, 提案法である FastICA を用いた構造変化検出を行った. FastICA にはVAR-ICA と同様に，512点の分離した推定信号を用いた. FastICA によって得られた分離行列 $F$ および，(16) 式によって 求めた残差を以下に示す。 また，残差を図示したものを 


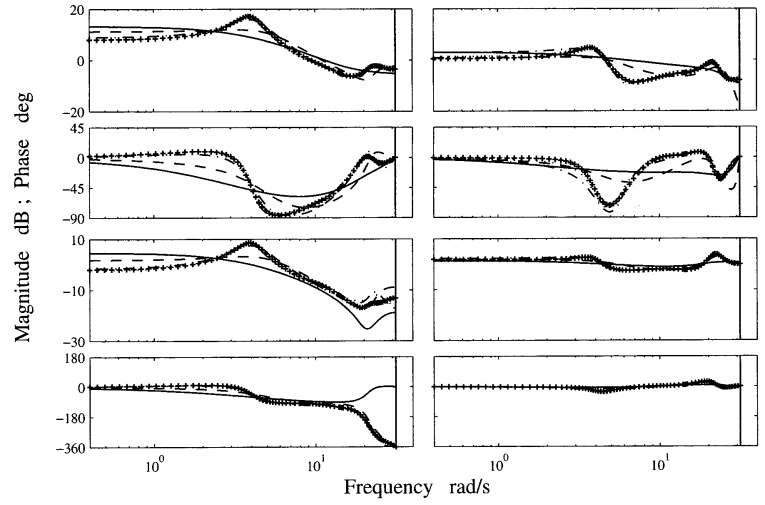

Fig. 7 Bode diagrams for $\mu=2,3, \ldots, 6$ (solid: $\mu=2$, dashed: $\mu=3$, dash-dotted: $\mu=4$, dotted: $\mu=5$, cross: $\mu=6$ )

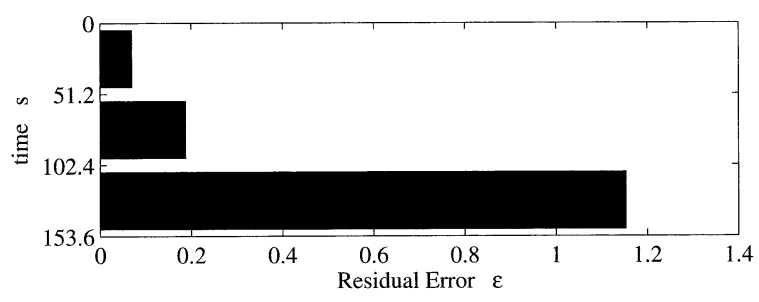

Fig. 8 Change detection using FastICA

Fig. 8 に示す.

$$
\begin{aligned}
& F_{1}=\left[\begin{array}{rr}
-0.574 & 10.754 \\
8.292 & -0.004
\end{array}\right], \quad \epsilon_{1}=0.069 \\
& F_{2}=\left[\begin{array}{rr}
-8.630 & 1.568 \\
-0.211 & 8.437
\end{array}\right], \quad \epsilon_{2}=0.187 \\
& F_{3}=\left[\begin{array}{rr}
4.706 & 4.519 \\
3.836 & -5.544
\end{array}\right],
\end{aligned}
$$

この図より 102.4 秒以降では残差が大きくなりシステ ムに構造上の変化が生じていることがわかる. FastICA を用いた処理にかかった時間は平均 0.53 秒と非常に短時 間で検出できることがわかった.

\section{5. おわりに}

本論文では，ICAを機械システムの構造変化検出に 応用し, 検出法の有効性を確認するために, 柔軟フレー ムの実験装置を製作し，それを用いた実験を行った。 VAR-ICA によるブラインド同定により逆システムを求 め，その逆システムから推定される入力信号の独立性を FastICA によって測ることで，より短時間での構造変化 の検出が可能であることを実験により確認した.

なお，本論文ではVAR-ICA と FastICAを併用して いるが，これらの独立性基準は異なるので， $H(z)$ を確 定した直後に得られる $F$ が対角行列になることが理論的 に保証されているわけではない. シミュレーションおよ び実験では対角になっているが，さらに厳密に変化検出
を行うには, 正常時に得られる定数分離行列 $F_{1}$ を基準 とし，それ以降に得られる $F_{n}$ については $F_{n} F_{1}^{-1}$ の対角 優位性を(16) 式で測るといった方法が考えられる。これ については今後の課題としたい.

また，実用に向けては，実際の環境に即した構造変化 検出に取り組む必要がある。たとえば入力が互いに干渉 し合う場合である。この場合は，分離信号が個々の独立 成分とはならないため，グループ間での独立性を議論し なければならない。この際，独立の判定にはブロック対 角行列を考えることになるが，グループの再編を考慮に 入れるなどの措置が必要となる。これについても今後の 課題としたい.

謝辞

5.の今後の課題について有益な示唆をいただいた査読 者に感謝します。

\section{参 考文献}

[1] S. Amari, A. Cichocki and H. Yang: A new learning algorithm for blind signal separation; Advances in Neural Information Processing Systems 8, MIT Press (1996)

[2] A. Hyvärinen and E. Oja: Fast fixed-point algorithm for independent component analysis; Neural Computation, Vol. 9, No. 7, pp. 1483-1492 (1997)

[3] A. Bell and T. Sejnowski: An information maximisation approach to blind separation and blind deconvolution; Neural Computation, Vol. 7, No. 6, pp. 1129 1159 (1995)

[4] S. Ikeda and N. Murata: A method of ICA in timefrequency domain; 1st International Conference on Independent Component Analysis and Signal Separation (1999)

[5] J. Karhunen, E. Oja, L. Wang, R. Vigário and J. Joutensalo: A class of neural networks for independent component analysis; IEEE Trans. Neural Networks, Vol. 8, No. 3, pp. 486-503 (1997)

[6] H. Yang and S. Amari: Adaptive On-line learning algorithms for blind separation: Maximum entropy and minimum mutual information; Neural Computation, Vol. 9, pp. 1457-1482 (1997)

[7] 中迫, 小倉 : 独立成分分析の基礎と音響信号処理 ; シス テム/制御/情報, Vol. 46, No. 7, pp. 400-408 (2002)

[8] 小谷, 有本, 小澤:独立成分分析による漏洩音検出に関す る検討 ; システム制御情報学会論文誌, Vol. 16, No. 10, pp. 539-547 (2003)

[9] 和久屋, 山下, 信太：頭部生体モデルを用いた脳内部温 度の推定: 独立成分分析による温度变化検出の可能性； 信学技報, MBE2001-153 (2002)

[10] N. Tsumura, H. Haneishi and Y. Miyake: Independent component analysis of skin color image; Journal of Optical Society of America, Vol. 16, No. 9, pp. 2169-2176 (1999) 
[11] 加納, 田中, 丸田, 長谷部, 橋本, 大野: 外部分析と独 立成分分析を用いた統計的プロセス運転監視; 計測自動 制御学会論文集, Vol. 38, No. 11, pp. 958-965 (2002)

[12] 新田, 杉本：Kullback-Leibler 情報量に基づく多変量 $\mathrm{AR}$ モデルのブラインド同定; 計測自動制御学会第 33 回 制御理論シンポジウム, pp. 225-228 (2004)

[13] 新田, 杉本, 佐藤 : 独立成分分析を用いた自己回帰モデ ルの未知入力同定法; 計測自動制御学会論文集, Vol. 41, No. 5, pp. 444-451 (2005)

[14] K. Sugimoto and M. Nitta: Polynomial matrix approach to independent component analysis: (Part I) Basics; IFAC World Congress (2005)

[15] M. Nitta and K. Sugimoto: A BSD approach to estimation and suppression of disturbance with unknown dynamics by $H^{\infty}$ feedback; IFAC Workshop on $A L$ COSP (2004)

[16] A. Hyvärinen, J. Karhunen and E. Oja: Independent Component Analysis, John Wiley \& Sons, pp. 355370 (2001) 